\title{
Verapamil as Alternative Treatment in Hypertrophic and Keloid Scars
} Guillermo Ramos-Gallardo1*, Diego Ricardo Delgado-Hernández ${ }^{1}$, José Alberto Cervantes-López², Alexis Ivan García-Minjarez ${ }^{1}$, Damaris
Leticia Núñez-González', Sandra Figueroa-Jiménez ${ }^{3}$ and Leonel García-Benavides ${ }^{4}$

${ }^{1}$ Universidad de Guadalajara, Centro Universitario de la Costa, Mexico

${ }^{2}$ Hospital Valentín Gómez Farías ISSSTE, Mexico

${ }^{3}$ Practica Privada, Unidad Médica Especializada, Mexico

${ }^{4}$ Antiguo Hospital Civil de Guadalajara, Fray Antonio Alcalde, Mexico

\begin{abstract}
Hypertrophic and keloid scars represent one of the main aesthetic and functional defects in patients after trauma, surgery, or burn. There are different therapeutic approaches used for these conditions, each showing varied results. Verapamil is a selective L-type calcium channel antagonist, which is currently considered as an alternative treatment in hypertrophic and keloid scars. Verapamil reduces the production of extracellular matrix, enhances collagenase secretion, and inhibits Interleukin 6 (IL-6), vascular endothelial growth factor (VEGF) and fibroblast cell proliferation. It also reduces the expression of transforming growth factor beta 1 (TGF- $\beta 1$ ), subsequently inducing apoptosis. Verapamil is hereby proposed as an alternative and effective therapy for hypertrophic and keloid scars.
\end{abstract}

Keywords: Keloid; Hypertrophic scar; Treatment; Verapamil

\section{Introduction}

Keloid and hypertrophic scars are abnormal, benign connective tissue neoplasms of unknown etiology. Histologically these abnormal scars are characterized by an increased amount of fibroblasts and accumulated collagen products. They are more common in Asians, Hispanics and African-Americans, and they are one of the main aesthetic and functional complications attended by surgeons $[1,2]$. The annual incidence of keloids in the developed world is estimated to be 11 million new cases, which is probably an underestimation [3]. There are many therapeutic approaches for these pathologies, each showing varied results; however treatment options are not always satisfactory and different alternatives have been researched.

Verapamil is a selective L-type calcium channel antagonist, which blocks the calcium influx of the extracellular matrix into the cytoplasm, thus reducing the cytosolic concentration of this ion and inducing a series of morphological and functional changes. It is currently considered a therapeutic option in the management of hypertrophic and keloid scars because of its many effects. Verapamil reduces the production of extracellular matrix, enhances collagenase secretion, inhibits IL-6, VEGF and fibroblasts proliferation and reduces the expression of TGF- $\beta 1$, subsequently inducing increased apoptosis [4].

\section{Predisposing factors for hypertrophic and keloid scars}

Hypertrophic and keloid scars are originated by injuries and skin irritation caused by any of the following: trauma, insect bites, burns, surgery, vaccination, skin piercing, acne, folliculitis, chicken pox, herpes zoster infection, etc. Superficial lesions that do not reach the reticular dermis do not cause these types of scars. This finding suggests that pathological scars are due to an injury in the reticular dermis and a subsequent defect in the healing process of the wound. The latter is characterized by continuous and histologically localized inflammation. As a result, the reticular dermis in keloid and hypertrophic scars contains inflammatory cells, increased number of fibroblasts, newly formed blood vessels, and collagen deposits [5].

Mechanical stress, age, anatomical location, growth factors, and hormones influence the development of these scars; several genetic factors have also been identified [6]. It has been determined that the excessive deposition of collagen glycosaminoglycan and growth factors (PDGF, TGF- $\beta$ and FCPI) plays an important role on the deformed appearance of the scar $[4,7]$.
Although a specific hereditary pattern has not been demonstrated, keloid and hypertrophic scars are more common in individuals of the same family. Marneros observed this phenomenon on three different generations and described an anomaly in the chromosomal loci $2 \mathrm{q} 23$ and $7 \mathrm{p} 11[8,9]$.

These pathological scars are more common in young people aged from 10-30 years old, with a higher prevalence during puberty and among pregnant women. In addition, any individual, regardless of his race, is susceptible; however, Asians and African-Americans show a higher susceptibility (up to 15\%). There are no reports in patients with albinism, suggesting that melanocytes probably play an important role in the development of these conditions. Lastly, there appears to be a relation between people with type A blood group and hypertrophic and keloid scars.

The way to prevent pathological scars has not been found given that its diverse etiologies are not fully understood. However, in regards to treatment, it is better to start during the initial stage, when the healing process is still active, and the scar is immature.

\section{Most common areas for pathological scars}

These benign connective tissue neoplasms are more common in parts of the body where there is more tension, for example the shoulders, back or chest [10]. On the other hand, different authors have identified areas where these types of scars could hardly be developed and named them as "non-keloid areas", such as: eyelids, genitals, palms of the hands and soles of the feet $[8,11]$.

\section{Cellular and molecular mechanisms of repair for normal and abnormal damage}

The pathogenesis of keloids usually starts after injury or

*Corresponding author: Guillermo Ramos-Gallardo, Universidad de Guadalajara Centro Universitario de la Costa, Av. Universidad 203, Ixtapa, 48280 Puerto Vallarta, Jal, México, Tel: 52322226 2200; E-mail: guiyermoramos@hotmail.com

Received June 26, 2017; Accepted September 06, 2017; Published September 13, 2017

Citation: Ramos-Gallardo G, Delgado-Hernández DR, Cervantes-López JA García-Minjarez Al, Núñez-González DL, et al. (2017) Verapamil as Alternative Treatment in Hypertrophic and Keloid Scars. Pigmentary Disorders 4: 265 doi:10.4172/2376-0427.1000265

Copyright: () 2016 Ramos-Gallardo G, et al. This is an open-access article distributed under the terms of the Creative Commons Attribution License, which permits unrestricted use, distribution, and reproduction in any medium, provided the original author and source are credited. 
inflammation of the skin in predisposed patients. Keloids develop as early as 1-3 months after the injury, but some may appear up to a year later. There is an increase in the production of metalloproteinase of the collagen matrix [8]. The use of in vitro systems has helped to identify many of the components that interact during the wound healing process. Many of these interactions are mediated through cell adhesion receptors called integrins. Often, its expression is regulated by cytokines and growth factors, such as TGF- $\beta$.

Proteolytic degradation of the extracellular matrix is an essential feature of tissue repair and remodeling processes. Plasminogen activator (PA), serine plasmin protease, and matrix metalloproteinases form the two major groups of degradation enzymes that interact and initiate a lysis cascade for the remodeling of the extracellular matrix (Figure 1). The main function of PA is to control the activation of plasminogen into plasmin. Plasmin is not only the primary enzyme in fibrinolysis - it also participates in the degradation of other extracellular matrix proteins, and activates procollagenase into collagenase. Thus, the initiation of PA proteinase cascade promotes proteolytic activity.

The complexity of this regulatory system is increased by the fact that active plasmin can release TGF [12]. TGF regulates the activation of plasminogen activator inhibitor 1 (PAI-1) in the extracellular matrix, tissue inhibitor of metalloproteinases 1 (TIMP-1) and genes that encode components of the extracellular matrix and integrin receptors [13].

TGF- $\beta$ has been mentioned as an example of a growth factor that participates in this process; it has a wide range of activities, not only in the normal scar but also in the fibrotic damage occurring during the repair. Many other growth factors such as epidermal growth factor (EGF), fibroblast growth factor (FGF) and platelet-derived growth factor (PDGF) have also a substantial influence on the growth and differentiation of keratinocytes, fibroblasts and endothelial cells present during wound repair.

The repair of the wound takes place through the interaction of the adhesive of the fibroblasts with its surrounding extracellular matrix. Many of these interactions are mediated by integrins. Expression of the integrin is regulated by growth factors, such as TGF- $\beta$, which is secreted in its latent form (linked to a latency-associated protein) and can be activated by plasmin. TGF- $\beta$ binds to fibroblasts through its heterodimeric receptor and regulates the cellular production of extracellular matrix, proteases (PA and collagenase) and protease inhibitors (PAI and TIMP).

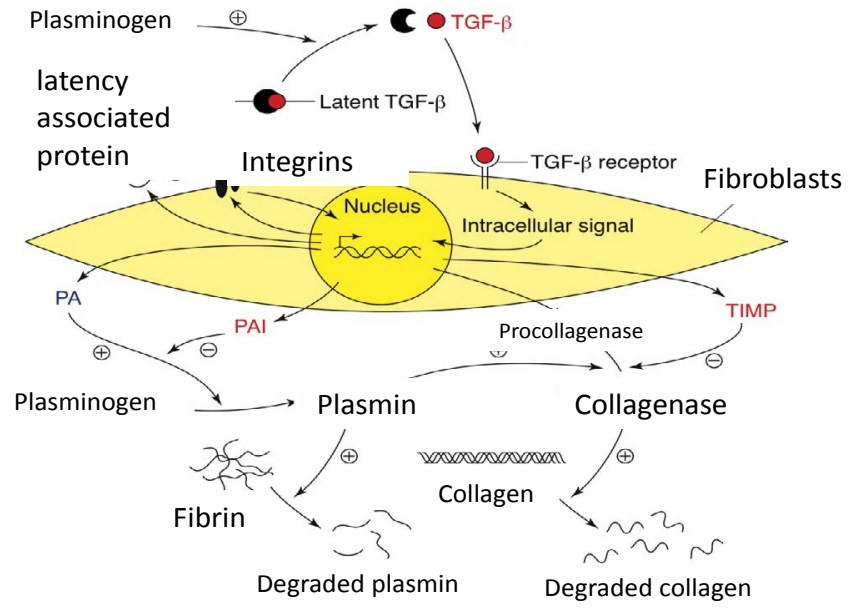

Figure 1: Cascade of activation of the process of healing

\section{Verapamil as a Therapeutic Alternative}

Lee reported the first case in which verapamil was used for the treatment of a burn scar. A few articles discuss the use of verapamil as treatment for pathological scars. Intralesional injection of calcium channel antagonists after keloid excision has shown promising initial results in three clinical trials. In other studies intralesional verapamil was successfully used in combination with pressure therapy and topical use of silicone. There are no significant adverse events of intralesional verapamil reported in these trials. The inhibition of calcium-dependent reactions involved in the production of extracellular matrix leads to improved degradation of the extracellular matrix [14-18].

Eray performed a study that included 22 patients with keloid scar treated with a combination of surgery and verapamil injection. Patients were evaluated for 2 years. They reported long-term improvement of symptoms, decrease in thickness of the keloid, and increased satisfaction [15]. In the last few years, many other studies have further supported the effectiveness of verapamil as an alternative treatment for pathological scars showing results similar to the ones achieved with steroids therapy.

The Department of Burns, Plastic, Maxillofacial, and Microvascular Surgery, Lok Nayak Hospital and the Maulana Azad Medical College, New Delhi, conducted a randomized trial in 2013, which compared post-surgical scars of burns and trauma. They evaluated the effectiveness of intralesional treatment. The use of concomitant therapies such as massage, silicone gel, or pressure garments was excluded from the study. The study showed evidence of the flattening of raised scars due to verapamil in both hypertrophic and keloid scars.

A 2004 study by the Journal of Burn Care \& Rehabilitation states that surgical removal with W-plasty or skin graft and intralesional injection of verapamil may be a good alternative for the treatment of keloids $[19,20]$.

With an exceptionally low cost and fewer adverse effects, verapamil deserves better positioning in the broad therapeutic armamentarium against hypertrophic scars. It also offers the therapeutic possibility to be alternated with triamcinolone or to be used simultaneously in larger (or multiple) scars. Another therapeutic option is surgery in combination with intralesional verapamil. It is known that no single technique has proven to be the definitive therapeutic solution, and better results have been observed in combined therapies than in any single treatment modality.

In regards to the specific advantages of verapamil, one of the most important would be its low rate of local adverse effects. As in any injection in connective tissue, the patient may experience pain at the injection site and recurrence in variable rates (less than $50 \%$ of cases). It is important to mention that other therapeutic options such as interferon, bleomycin, 5-FU and steroids have shown higher incidence of adverse effects [21,22] (Table 1).

We used verapamil in patients with keloid and hypertrophic burn injuries. We found an improvement in the symptomatology with reduction of pruritus, pain, pliability and better overall performance in the Vancouver and Posas Scales. Treatment can be applied once every 7 days up to once every 3 weeks. We evaluated scars with POSAS and Vancouver Scar Scale (VSS) before treatment. After four injections the lesions were reevaluated and if needed, 4 injections were further applied. We found it to be a valuable therapeutic asset in patients who do not respond or have adverse effects after treatment with triamcinolone [23]. We observed pain after injection with either triamcinolone or 
Citation: Ramos-Gallardo G, Delgado-Hernández DR, Cervantes-López JA, García-Minjarez Al, Núñez-González DL, et al. (2017) Verapamil as Alternative Treatment in Hypertrophic and Keloid Scars. Pigmentary Disorders 4: 265. doi:10.4172/2376-0427.1000265

Page 3 of 3

\begin{tabular}{|c|c|c|}
\hline Drug & Dose & Adverse Effects/Disadvantages \\
\hline 5-FU & $40-50 \mathrm{mg} / \mathrm{mL}$ & $\begin{array}{l}\text { - Ulceration of the wound } \\
\text { - Hyperpigmentation } \\
\text { - Atrophy } \\
\text { - Erythema } \\
\text { - Tissue detachment } \\
\text { - Swelling } \\
\text { - Pain } \\
\text { - Telangiectasia }\end{array}$ \\
\hline Bleomycin & $\begin{array}{l}\text { Multiple needle punctures } \\
\text { or bleomycin injection }(1.5 \\
\mathrm{IU} / \mathrm{ml})\end{array}$ & $\begin{array}{l}\text { - Erythema } \\
\text { - Hyperpigmentation } \\
\text { - Raynaud Phenomenon } \\
\text { - Gangrene } \\
\text { - Fibrosis } \\
\text { - Neutrophilic eccrine hidradenitis } \\
\text { - Necrosis of keratinocytes } \\
\text { - Alopecia } \\
\text { - Edema } \\
\text { - Nail changes } \\
\text { - Moderately expensive }\end{array}$ \\
\hline Interferon & $\begin{array}{l}1.5 \text { million IU } \\
\text { mg IFN-c }\end{array}$ & $\begin{array}{l}\text { - Flu-like symptoms } \\
\text { - Pain at the injection site } \\
\text { - Erythema local } \\
\text { - Edema } \\
\text { - Expensive }\end{array}$ \\
\hline Cryotherapy & $\begin{array}{l}\text { Needle inserted into the } \\
\text { keloid scar and connected } \\
\text { to a liquid nitrogen canister, } \\
\text { freezing at } 20 \mathrm{~mm} \text { depth }\end{array}$ & $\begin{array}{l}\text { - Very expensive } \\
\text { - Slight hypopigmentation }\end{array}$ \\
\hline Verapamil & $\begin{array}{l}\text { Intralesional verapamil } \\
(2.5 \mathrm{mg} / \mathrm{ml}) \\
0.5 \mathrm{ml} / 2.0 \mathrm{ml} \\
\text { Administered each time, } \\
\text { depending on the size of } \\
\text { the keloid }\end{array}$ & $\begin{array}{l}\text { - Pain at the injection site } \\
\text { - Variable recurrence }\end{array}$ \\
\hline
\end{tabular}

Table 1: Use of medication

verapamil. However, since triamcinolone is applied every 3-4 weeks, it is preferred to start with it instead of verapamil.

The use of verapamil should be reserved for the following clinical settings: To reduce the incidence of keloid recurrence clinically after surgical excision and topical silicone application; to reduce keloids (in up to $55 \%$ ) after surgical excision followed by pressure dressings; and as an alternative to triamcinolone, to reduce the incidence of adverse effects [24].

\section{Conclusion}

Knowing that there is no ideal treatment for all patients with pathological scars, new alternatives should be considered, and verapamil is an acceptable path of therapeutic action. It has demonstrated its effectiveness in reducing extracellular matrix production, inducing fibroblast procollagenase synthesis and inhibiting interleukin-6, VEGF, and cellular proliferation of fibroblasts. It also inhibits proliferation and TGF- $\beta 1$ expression in fibroblasts and induces apoptosis. For patients, it represents a feasible option since this medication has a low cost, its adverse effects are minimal compared to other therapeutic alternatives, and verapamil in combination with other therapeutic options such as compression garments or surgery has shown better overall results.

\section{Refrences}

1. Shaffer JJ, Taylor SC, Cook-Bolden F (2002) Keloidal scars: A review with a critical look at therapeutic options. J Am Acad Dermatol 46: 63-97.

2. Huang C, Akaishi S, Hyakusoku H, Ogawa R (2012) Are keloid and hypertrophic scar different forms of the same disorder? A fibroproliferative skin disorder hypothesis based on keloid findings. Int Wound J 11: 517-522.

3. Ochoa-Pell JA (2008) Conceptos Actuales en cicatrización queloide. Rev Sanid Molit Mex 62: 97-101.

4. Wang R, Mao Y, Zhang Z, Li Z, Chen J, et al. (2015) Role of verapamil in preventing and treating hypertrophic scars and keloids. Int Wound J 13: 461 468.

5. Ogawa R (2017) Keloid and hypertrophic scars are the result of chronic inflammation in the reticular dermis. Int J Mol Sci 18: 606.

6. Jones K, Fuller CD, Luh JY, Childs CC, Miller AR, et al. (2006) Case report and summary of literature: Giant perineal keloids treated with post-excisional radiotherapy. BMC Dermatol 6: 7 .

7. Lee SS, Yosipovitch G, Chan YH, Goh CL (2004) Pruritus, pain, and small nerve fiber function in keloids: A controlled study. J Am Acad Dermatol 51: 1002-1006.

8. Christian SZ, Alejandra VV, Pablo MP, Miguel CM (2002) Cicatrices hipertróficas y queloides. Cuad Cir 16: 77-86.

9. Marneros AG, Norris JEC, Olsen BR, Reichenberger E (2001) Clinical genetics of familial keloids. Arch Dermatol 137: 1429-1434.

10. Bayat A, Arscott G, Ollier W, Ferguson M, Mc Grouther DA (2004) Description of site-specific morphology of keloid phenotypes in an Afrocaribbean population. Br J Plast Surg 57: 122-133.

11. Robles DT, Berg D (2007) Abnormal wound healing: keloids. Clin Dermatol 25 26-32.

12. Fujiwara M, Muragaki Y, Ooshima A (2005) Keloid-derived fibroblasts show increased secretion of factors involved in collagen turnover and depend on matrix metalloproteinase for migration. Br J Dermatol 153: 295-300.

13. Ledon J, Savas J, Franca K, Chacon A (2013) Intralesional treatment for keloids and hypertrophic scars: A review. Dermatol Surg 39: 1745-1757.

14. Skaria A (2004) Prevention and treatment of keloids with intralesional verapamil. Dermatology 209: 71.

15. Copcu E, Sivrioglu N, Oztan Y (2004) Combination of surgery and intralesional verapamil injection in the treatment of the keloid. J Burn Care Rehabil 25: 1-7.

16. Lawrence WT (1996) Treatment of earlobe keloids with surgery plus adjuvant intralesional verapamil and pressure earrings. Ann Plast Surg 37: 167-169.

17. Lee RC, Ping JA (1990) Calcium antagonists retard extracellular matrix production in connective tissue equivalent. J Surg Res 49: 463.

18. Doong H, Dissanayake S, Gowrishankar TR, LaBarbera MC, Lee RC (1996) The 1996 Lindberg Award: Calcium antagonists alter cell shape and induce procollagenase synthesis in keloid and normal human dermal fibroblasts. J. Burn Care Rehabil 17: 497.

19. Prado AS, Fontbona M (2006) A 1.8-kg Keloid of the Arm. Plast Reconstr Surg 117: 335-336.

20. Cosman B, Crikelair GF, Ju DMC, Gaulin JC, Lattes R (1961) The surgical treatment of keloids. Plast Reconstr Surg 27: 335-358.

21. Trisliana Perdanasari A, Lazzeri D, Su W, Xi W, Zheng Z, et al. (2014) Recent developments in the use of intralesional injections keloid treatment. Arch Plast Surg 41: 620.

22. Ahuja RB, Chatterjee $P$ (2014) Comparative efficacy of intralesional verapam hydrochloride and triamcinolone acetonide in hypertrophic scars and keloids. Burns 40: 583-588

23. Ramos-Gallardo G, Miranda-Altamira A, Valdes-López R, Figueroa-Jimenez F Garcia-Benavides $L$ (2016) Verapamil in conjunction with pressure therapy in the treatment of pathologic scar due burn injury. Rev Med Inst Mex Seguro Soc 54: 454-457.

24. Ledon JA, Savas J, Franca K, Chacon A, Nouri K (2013) Intralesional treatment for keloids and hypertrophic scars: A review. Dermatol Surg 39: 1745-1757. 